\title{
Advances in natural stable isotope ratio analysis of human hair to determine nutritional and metabolic status Klaus J. Petzke ${ }^{\mathrm{a}}$, Benjamin T. Fuller ${ }^{\mathrm{b}, \mathrm{c}}$ and Cornelia C. Metges ${ }^{\mathrm{d}}$
}

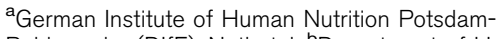
Rehbruecke (DIfE), Nuthetal, ${ }^{\mathrm{b}}$ Department of Human Evolution, Max Planck Institute for Evolutionary Anthropology, Leipzig, Germany, 'Laboratory of Animal Biodiversity and Systematics, Centre for Archaeological Sciences, Katholieke Universiteit Leuven, Leuven, Belgium and dLeibniz Institute of Farm Animal Biology (FBN), Dummerstorf, Germany

Correspondence to Dr Klaus J. Petzke, Deutsches Institut für Ernährungsforschung (German Institute of Human Nutrition), Arthur-Scheunert-Allee 114-116, D-14558 Nuthetal, Germany

Tel: +49 33200 88429; fax: +49 3320088331 ; e-mail: petzke@dife.de

Current Opinion in Clinical Nutrition and Metabolic Care 2010, 13:532-540

\section{Purpose of review}

We review the literature on the use of stable isotope ratios at natural abundance to reveal information about dietary habits and specific nutrient intakes in human hair protein (keratin) and amino acids. In particular, we examine whether hair isotopic compositions can be used as unbiased biomarkers to provide information about nutritional status, metabolism, and diseases.

\section{Recent findings}

Although the majority of research on the stable isotope ratio analysis of hair has focused on bulk protein, methods have been recently employed to examine amino acid-specific isotope ratios using gas chromatography or liquid chromatography coupled to an isotope ratio mass spectrometer. The isotopic measurement of amino acids has the potential to answer research questions on amino acid nutrition, metabolism, and disease processes and can contribute to a better understanding of the variations in bulk protein isotope ratio values. First results suggest that stable isotope ratios are promising as unbiased nutritional biomarkers in epidemiological research. However, variations in stable isotope ratios of human hair are also influenced by nutrition-dependent nitrogen balance, and more controlled clinical research is needed to examine these effects in human hair.

\section{Summary}

Stable isotope ratio analysis at natural abundance in human hair protein offers a noninvasive method to reveal information about long-term nutritional exposure to specific nutrients, nutritional habits, and in the diagnostics of diseases leading to nutritional stress and impaired nitrogen balance.

\section{Keywords}

human hair, nutritional biomarker, protein and amino acids, stable isotope analysis

Curr Opin Clin Nutr Metab Care 13:532-540

(C) 2010 Wolters Kluwer Health | Lippincott Williams \& Wilkins 1363-1950

\section{Introduction}

Hair as a medium to analyze toxic and organic substances such as heavy metals, heroin, and other drugs has been a focus of research for over the past 30 years [1]. However, the analyses of the stable isotope ratios $\left({ }^{2} \mathrm{H} /{ }^{1} \mathrm{H},{ }^{13} \mathrm{C} /{ }^{12} \mathrm{C}\right.$, ${ }^{15} \mathrm{~N} /{ }^{14} \mathrm{~N},{ }^{18} \mathrm{O} /{ }^{16} \mathrm{O}$, and ${ }^{34} \mathrm{~S} /{ }^{32} \mathrm{~S}$ ) of hair protein have only recently been recognized to provide information about dietary habits and the metabolic status of prehistoric and modern humans, eating disorders, forensic medicine, geographical location, and wildlife dietary ecology [2$\left.6,7^{\bullet}, 8,9^{\bullet}, 10-14\right]$. The vast majority of this research has been focused on bulk protein isotopic analysis at natural abundance, but recent advances in isotope ratio mass spectrometry (IRMS) now allow the measurement of individual compounds such as amino acids. As amino acids represent the fundamental compounds of hair protein, they have the potential to provide powerful new insights into the dietary, physiological, and environmental patterns of humans.

Hair as an ideal medium for isotopic analysis As the fibrous protein structure of hair (keratin) is extremely resistant to degradation, it can preserve isotopic information over thousands of years, thus making it possible to reconstruct dietary and physiological conditions of ancient human populations. In this respect, it is surprising that it was not until the late 1990s that hair was recognized as a superior material to study the dietary history of modern and archaeological humans [2,15]. Hair is an ideal medium for stable isotope ratio analysis in modern clinical nutritional studies for the following reasons. First, hair can be noninvasively sampled in humans by cutting or minimally invasively sampled by pulling from the scalp. Second, hair protein is 
metabolically inert after it is synthesized, and thus, can record a long-term dietary history of physiological conditions or exposures. Important in our context, hair has been found to be isotopically representative of the body protein pool, and its isotopic composition was found to reflect those of the dietary protein sources in addition to metabolic and environment influences $\left[2-4,8,9^{\circ}, 10-\right.$ $12,15]$. Human scalp hair grows at a rate of approximately $1 \mathrm{~cm}$ per month, and thus, the isotopic signatures may be recorded linearly along the length of a hair by segmental analysis [16]. However, only about $85 \%$ of the hair of an adult is in the growing phase (anagen), whereas the remaining is in a resting phase (telogen) following a transition stage for completion of keratinization $[1,16]$. Recent isotopic information may be lost by cutting, as the hair follicles are located about $3 \mathrm{~mm}$ below the surface of the skin. Nevertheless, different growth rates and proportions of anagen/telogen hairs are known for anatomically different parts of the body as well as for differences based on race, sex, age, and health $[1,15,16]$. Atmospheric contaminations, cosmetic treatments, and graying were shown not to affect stable isotope ratios in hair if washed appropriately to remove lipid and shampoo residues, but dying and bleaching may subtly alter the isotopic ratios $[2,15,16]$.

\section{Measurement of hair isotopic values}

The preferred method to measure stable isotope ratios at natural abundance in human hair is the highly sensitive and precise continuous flow IRMS. Development of IRMS systems has been an active area of research for the past 30 years, but commercially available instruments were first available in the early 1990s, which spurred an increase in applications to medical and nutritional research. The reader is directed toward several reviews that summarize the present state of instrumentation, technologies, practical demands, and research applications involving IRMS [17-24].

The most common interfaces used to introduce samples on-line into the IRMS are elemental analyzers that oxidize samples at approximately $1000^{\circ} \mathrm{C}$ (elemental analyzer-IRMS) or IRMS systems that pyrolize samples at approximately $1400^{\circ} \mathrm{C}$ (thermoconversion/elemental analyzer-IRMS) for the determination of bulk organic material $\delta^{13} \mathrm{C}, \delta^{15} \mathrm{~N}$, and $\delta^{34} \mathrm{~S}$ or $\delta^{2} \mathrm{H}$ and $\delta^{18} \mathrm{O}$ values, respectively. Due to the very small differences in natural isotopic composition between molecules or small variations of the heavier isotope in the presence of large amounts of the lighter isotope, a special $\delta$-notation is used due to convention designating the isotopic abundance as parts per 1000 (per mil) deviation from an international standard: $\delta_{\text {sample }}(\%)=\left[\left(R_{\text {sample }} / R_{\text {standard }}\right)-1\right] \times 10^{3}$, where $R_{\text {sample }}$ is the measured isotope ratio of the sample and $R_{\text {standard }}$ for the isotope ratio of the respective international standard $[17,18,22,25]$.
Improved instrumentation has facilitated measurements of $\mathrm{H}$ and $\mathrm{O}$ isotopes and their analyses in hair have now become routine in some laboratories $\left[6,7^{\bullet}, 26-28\right]$. Recently, a new method has been introduced enabling longitudinal measurements of $\delta^{34} \mathrm{~S}$ values in single hair strands based on a laser ablation system coupled to a multicollector inductively coupled plasma mass spectrometer (MC-ICP-MS) specific for sulfur-containing amino acids cysteine and methionine [29]. MC-ICPMS can also be employed alternatively to IRMS for $\delta^{13} \mathrm{C}[30]$. However, this bulk analysis does not allow for detailed investigations of specific pathways and turnover rates of the specific amino acids.

Advances in IRMS technology now allow on-line compound-specific isotope analyses (CSIAs) of individual amino acids so that natural isotopic signatures can be examined at the molecular level. Previous off-line methods were time-consuming and required large sample sizes to study only some of the proteinogenic amino acids [31]. Recent techniques that couple the IRMS with gas chromatography and a combustion interface (GC-CIRMS) for $\delta^{13} \mathrm{C}$ and $\delta^{15} \mathrm{~N}$ or with a pyrolysis interface (GC-P-IRMS) for $\delta^{2} \mathrm{H}$ and $\delta^{18} \mathrm{O}$ now permit the on-line measurement of amino acids. However, accuracy and precision must be improved [32]. This is complicated by the fact that gas chromatographic separation is a major challenge as peaks must be baseline separated to achieve precise and accurate stable isotope ratio measurements $[17,22]$. In addition, amino acids must be derivatized (to make them volatile), which is problematic as this introduces additional carbon atoms, which also interferes with the precision and accuracy of the $\delta^{13} \mathrm{C}$ measurements. To minimize such potential problems, derivatives as $N$-acetylmethyl esters with a relatively high analyte-to-derivative carbon ratio may be used. Analytical errors of amino acid $\delta^{13} \mathrm{C}$ values have been detected with decreasing analyteto-derivative carbon ratios ranging from \pm 0.6 to $\pm 1.1 \%$ for leucine and glycine, respectively [33,34]. For comparison, bulk $\delta^{13} \mathrm{C}$ measurements generally have a precision below $0.2 \%$. Empirically determined amino acid-specific correction factors are absolutely necessary to correct for the additional derivatization carbon and for possible fractionation introduced by the derivatization process $[35,36]$.

Catalyst poisoning to the GC-C-IRMS combustion furnace may result in incomplete formation of reaction products when using silicone-containing derivatives as tert-butylmethylsilation or trifluoroacetyl isopropyl esters in addition to capillary column damage. It has been reported that nonquantitative reactions, the formation of by-products, instability of derivatives, and chromatographic resolution problems may result in significant errors. Nevertheless, acidic conditions during protein hydrolysis or subsequent derivatization can lead to destruction of several amino acids (amides) [17,33,34,37]. 
Summarizing, the method with which one has to select a dervatization agent should be according to the specific analysis involved and is particularly dependent on the amino acids and isotopes of interest. We have established and adapted a reliable method for $\delta^{13} \mathrm{C}$ and $\delta^{15} \mathrm{~N}$ analysis of individual amino acids by GC-C-IRMS and applied it in previous metabolic and nutritional studies [18,35,38]. It involves the use of $\mathrm{N}$-pivaloyl-i-propyl ester, which has either no or limited isotopic effects, introduces only a limited amount of derivatization carbon, does not damage excessively the combustion system, and satisfactorily separates individual amino acids accessible by this derivatization method. Unfortunately, the method is unsuitable for amide nitrogen, arginine, and cysteine (the most abundant amino acid in human hair) $[18,32,35,38]$. Methods have been reported describing highly precise intramolecular $\delta^{15} \mathrm{~N}$ measurements of amino acids, which can be of interest for amides, arginine, and lysine. However, the methods require either time-consuming enzymatic or chemical treatments of off-line separated amino acids and have not been applied routinely in human studies $[39,40]$.

Liquid chromatography coupled to IRMS (LC-IRMS) has been recently developed to study $\delta^{13} \mathrm{C}$ values in a variety of biological molecules. This technique does not require derivatization and best realizes the belief that 'the best derivatization for isotopic analysis is no derivatization at all' [23,41]. Modern LC-IRMS systems pass separated amino acids eluted with carbon-free inorganic mobile phases directly into a commercially available Thermo Scientific LC IsoLink (Bremen, Germany) [42]. Smith et al. [43] were the first to report a robust and reliable LC-IRMS method to measure natural abundance amino acid-specific $\delta^{13} \mathrm{C}$ values in human hair. With this method, 13 amino acids were baseline separated which is an essential prerequisite for precise and accurate CSIA. Future developments are directed toward improvement of chromatographic conditions to achieve better resolution and baseline separation of critical amino acid pairs (isoleucine and leucine, cystine and methionine) in hair and increasing sample throughput (currently $4 \mathrm{~h}: 15$ min per sample). Raghavan et al. [44] also obtained baseline resolution of 13 of the 18 protein-bound amino acids in human hair and validated the use of LC-IRMS on archaeological hair samples. Unfortunately, there are no reported applications of hair $\delta^{18} \mathrm{O}$ and $\delta^{2} \mathrm{H}$ CSIA of protein-bound amino acids. However, relationships between amino acid-specific $\delta^{18} \mathrm{O}$ and $\delta^{2} \mathrm{H}$ values and diet and metabolism of amino acids have to be expected, and is an area of future research $\left[7^{\bullet}, 27\right]$.

\section{Hair $\delta$-values can reflect the food consumed}

A fundamental aspect to the use of stable isotope ratio analysis in medical and nutritional studies is the finding that there is a correlation between $\delta$-values of ${ }^{15} \mathrm{~N},{ }^{13} \mathrm{C}$, and ${ }^{34} \mathrm{~S}$ of consumer tissues, including human hair keratin, with those of the food consumed [3,45-47]. Investigations in dietary reconstruction of archaeological specimens and in wildlife dietary ecology are based on this correlation. For example, the isotopic data of bone collagen show that the Neanderthals were top-level carnivores and obtained all of their dietary protein from large herbivores [48]. A sequential analysis of tail hair $\delta$-values of northern Kenyan elephants provided a weekly record of diet and water resources correlating with satellitebased measurements of the vegetation occupied [49]. It is also accepted that the $\delta$-values of ${ }^{2} \mathrm{H}$ and ${ }^{18} \mathrm{O}$ reflect the water ingested and which is also contained in local food and this provides information about geographical location and/or travel $\left[6,7^{\bullet}, 27,28,50\right]$.

In addition, it has been found that the $\delta$-values of consumer tissue proteins are higher relative to diet proteins by some per mil $(\%)$ value and this is known as trophic level effect $[8,51,52]$. The resulting slight enrichments of the heavy isotope of consumer tissue protein pools, including hair compared with those of food proteins are well documented for ${ }^{15} \mathrm{~N},{ }^{13} \mathrm{C}$, and ${ }^{34} \mathrm{~S}$ and can be quantified by a discrimination factor $\Delta=\delta_{\text {hair }}-\delta_{\text {diet }}$. $\Delta^{15} \mathrm{~N}_{\text {hair-diet }}$ values in the range of $4-5 \%$ have been reported, but were found to be lower for $\Delta^{13} \mathrm{C}$ and $\Delta^{34} \mathrm{~S}$ $(1-2 \%$ ) $[2,8,13,51,53-55]$. However, these discrimination factors appear not to be constant and vary according to species, tissue, age, growth rate, protein content of diets, and protein turnover rate, and can decrease with increasing $\delta$-values of diets [44,54].

Consequently, various food proteins can differ significantly in their isotopic composition [3,8,56]. Animalderived and marine-based dietary protein sources generally have greater stable isotope abundances $\left(\delta^{15} \mathrm{~N}, \sim 2-3 \%\right.$; $\delta^{13} \mathrm{C}, \sim 10 \%$ ) than those derived from plants $[3,47,57]$. This also can be shown by CSIA (Fig. 1 ). These isotopic differences between dietary protein sources and amino acids occur because of fractionation in metabolic pathways as a result of kinetic isotope effects of enzymatic reactions associated with bond-breaking and formation in the biosynthesis of organic compounds and in metabolism. Examples of the resulting isotope discriminations are well documented for $\delta^{13} \mathrm{C}$ (type of carbon fixation reaction during photosynthesis resulting in so-called $\mathrm{C}_{3}$ or $\mathrm{C}_{4}$ plants with median $\delta^{13} \mathrm{C}$ values of -27 or $-14 \%$, respectively [3,58]), and for $\delta^{15} \mathrm{~N}$ (amino acid transamination is suggested to be responsible for the relatively ${ }^{15} \mathrm{~N}$ depleted nitrogen excretion pool compared to body protein pool with a difference of about $10 \%$ $[59,60])$.

However, less is known about diet-related changes in hair $\delta^{2} \mathrm{H}$ and $\delta^{18} \mathrm{O}$ values. The interpretation here is more 
Figure 1 Comparison of amino acid-specific $\delta^{15} \mathrm{~N}$ values of wheat gluten, pork fillet (Germany), and hair of young German women consuming $200 \mathrm{~g}$ pork fillet per day in addition to their habitual diet for 4 weeks

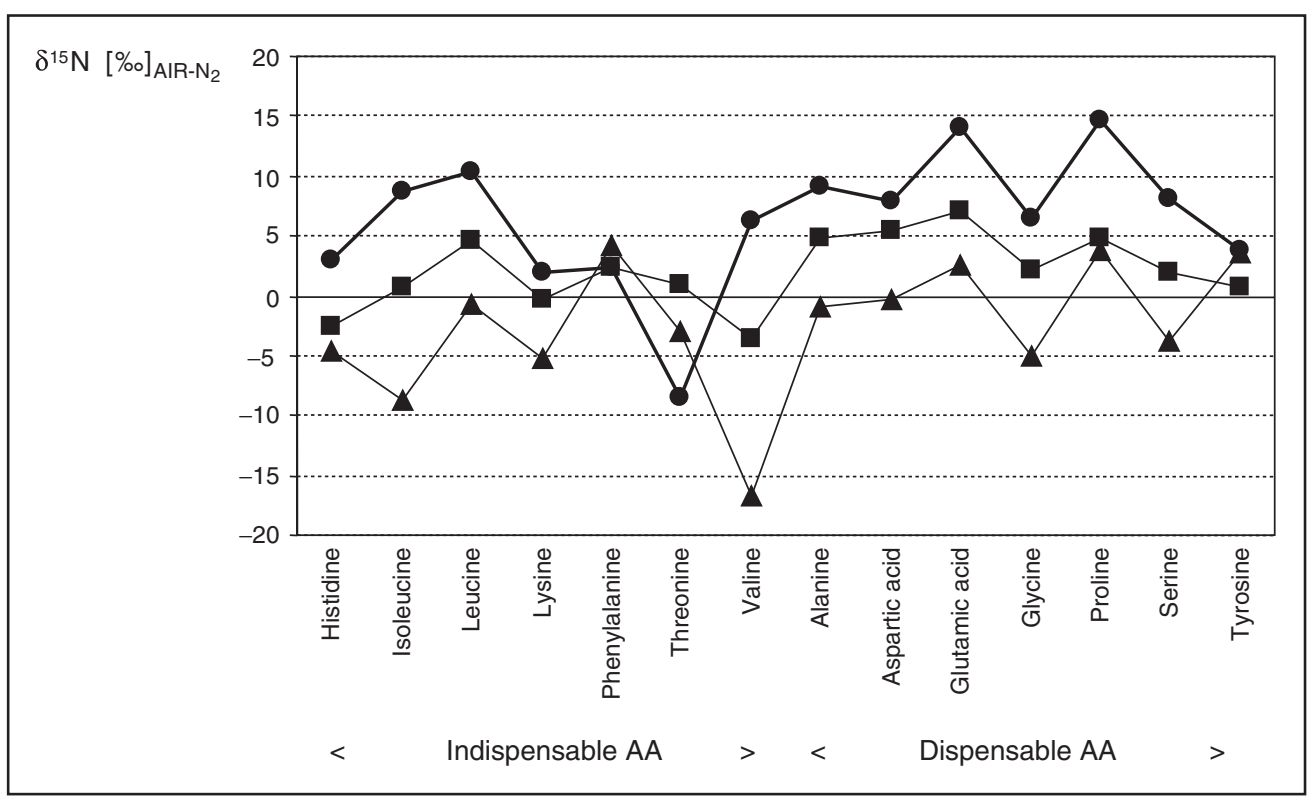

Note the comparable pattern and the $\Delta\left(\delta^{15} \mathrm{~N}\right)$ between sample sources. $\_-$, human hair; $\_$, pork fillet; $\_$, wheat gluten. AA, amino acid. Reproduced with permission from [32].

complicated because $\mathrm{H}$ and $\mathrm{O}$ can derive both from drinking water and diet. Recent data based on analysis of human hair samples and mass-balance modeling suggest a trophic level effect on $\delta^{2} \mathrm{H}$ values, primarily reflecting a mixing of ${ }^{2} \mathrm{H}$-enriched water and ${ }^{2} \mathrm{H}$ depleted food $\mathrm{H}$ in the body rather than fractionation during biosynthesis. Although hair $\delta^{2} \mathrm{H}$ and $\delta^{18} \mathrm{O}$ values were mostly controlled by variations in water isotope ratios, first data suggest influences related to dietary composition, especially in marine-based diets such as in hair samples from Inuit $\left[6,7^{\bullet}, 27\right]$.

\section{Hair $\delta$-values as biomarkers of long-term nutritional exposure}

Based on the previous studies, we and others assumed that the $\delta$-values of hair can be used as unbiased biomarkers to evaluate nutritional exposure [32,57,61]. Although detailed and controlled research in this area has only just begun, the first results support the potential of stable isotope ratios, particularly when using hair as a long-term recorder (Table 1) $\left[2,3,6,7^{\bullet}, 9^{\bullet}, 32,45,47,55-\right.$ $57,62-64]$. Benefits or health risks of nutrient intake are commonly predicted using self-reporting methods, which can be biased by under-reporting or over-reporting, which is a frequently observed phenomenon in dietary recall methods (discussed in [57,63]). Previous publications have demonstrated that bulk hair $\delta$-values are specific and sensitive in reflecting particular eating habits and nutrient intake associated with important clinical outcomes such as diabetes and metabolic syndrome, and this is essential for the appropriate development of biomarkers $[65,66]$. However, stable isotope ratio analysis has not been used in large-scale epidemiological studies. Another limitation of these early studies is the use of relatively small sample populations. Nevertheless, the power was sufficient to detect highly significant correlations between $\delta$-values and nutrient intakes $\left[9^{\bullet}, 57\right]$. However, the investigations were not extended to the CSIA level. Nonetheless, there is a need for adequate and controlled dietary intervention studies in humans to investigate the association between $\delta$-values and nutritional exposure [32,55]. Although some of such investigations were performed with animals $[10,13,67]$, there have been very few studies in this area involving humans $[32,55]$.

\section{Hair $\delta$-values as a diagnostic tool in disease}

Since the pioneering work of Schoenheimer and Rittenberg in the 1930s proving the theory of a dynamic equilibrium in proteins and lipids, stable isotope ratios have been used as tracers in nutrition and biomedicine $[68,69]$. However, only a few isotopic studies at natural abundance have examined metabolic state and diseases in humans (Table 2) $[11,12,52,55,60,70-74]$. Previous work by Fuller et al. [72,73] was the first to demonstrate in humans that the $\delta^{15} \mathrm{~N}$ values in bulk hair protein can be used to track changes in nitrogen balance during anabolic (pregnancy) and catabolic (morning sickness) 
Table 1 Human stable isotope ratio studies of hair and other tissues supporting the evidence of $\delta$-values as biomarkers of specific nutrient intake in relation to suggested health benefits or risks

\begin{tabular}{|c|c|c|}
\hline$\delta$-Values, sample & Main outcomes, background, and link to disease risk discussed & Reference \\
\hline${ }^{15} \mathrm{~N}$, hair, bulk & $\begin{array}{l}\text { Correlation with animal protein and meat intake (no correlation with }{ }^{13} \mathrm{C} \text { ) in a group } \\
\text { of } 28 \text { Oxford residents. }\end{array}$ & [2] \\
\hline${ }^{15} \mathrm{~N},{ }^{13} \mathrm{C}$, hair, bulk & $\begin{array}{l}\text { Clear distinction of food preference groups: omnivores, ovo-lacto-vegetarians, } \\
\text { and vegans; } \\
\text { Correlation with animal protein consumption in } 38 \text { residents of Okehampton area, } \\
\text { SW England. }\end{array}$ & [45] \\
\hline $\begin{array}{l}{ }^{15} \mathrm{~N},{ }^{13} \mathrm{C} \text {, hair, bulk and } \\
\text { amino acid CSIA }\end{array}$ & $\begin{array}{l}\text { Clear distinction of food preference groups: omnivores, ovo-lacto-vegetarians, and } \\
\text { vegans using } 126 \text { samples selected of a population-based cross sectional } \\
\text { study in Germany. } \\
\text { High predictability of animal protein and meat consumption in bulk values and first } \\
\text { results on CSIA of amino acid and its feasibility for predicting animal protein intake; } \\
\text { Intervention with additional meat consumption and meat omission failed to modify } \\
\delta \text {-values within } 4 \text { weeks in young woman, suspected to be caused by adaptations } \\
\text { to high-protein intake; } \\
\text { Higher amino acid-specific } \delta^{15} \mathrm{~N} \text { and lower } \delta^{13} \mathrm{C} \text { values after both additional meat } \\
\text { consumption and meat omission remain to be explained; } \\
\text { Background: suspected risk of high protein and meat consumption with cancer, } \\
\text { diabetes, and metabolic syndrome components, and benefit in weight-reducing diets } \\
\text { and in conservation of lean body mass. }\end{array}$ & {$[3,32,57]$} \\
\hline${ }^{15} \mathrm{~N},{ }^{13} \mathrm{C}$, hair, bulk & $\begin{array}{l}\text { Abrupt change of "German" diet to } \mathrm{C}_{4} \text { (about }+9 \% \delta^{13} \mathrm{C} \text { ) and marine-based } \\
\text { (about }+2 \% \delta^{15} \mathrm{~N} \text { ) diet; } \\
\text { Significant increases in } \delta \text {-values within } 28 \text { days in all four participants. }\end{array}$ & [55] \\
\hline $\begin{array}{l}{ }^{15} \mathrm{~N},{ }^{13} \mathrm{C},{ }^{34} \mathrm{~S} \text {, bulk, } \\
\text { fingernails }\end{array}$ & $\begin{array}{l}\text { Significantly enriched in } 82 \text { North Greenland Inuit compared to } 32 \text { Danes living in } \\
\text { Denmark based on high marine food consumption. } \\
\text { Background: lower risk of marine-based diet with high } \omega-3 \text { fatty acid content for ischemic } \\
\text { heart diseases. }\end{array}$ & {$[47]$} \\
\hline $\begin{array}{l}{ }^{15} \mathrm{~N},{ }^{13} \mathrm{C} \text {, red blood } \\
\text { cells, bulk }\end{array}$ & $\begin{array}{l}\text { Significant enrichment in }{ }^{15} \mathrm{~N} \text {, but depletion in }{ }^{13} \mathrm{C} \text { in } 12 \text { elders compared to } 14 \text { younger } \\
\text { Alaskan natives consistent with higher intake of marine food in elders and market } \\
\text { (corn-based) food in younger participants. }\end{array}$ & {$[62]$} \\
\hline $\begin{array}{l}{ }^{15} \mathrm{~N} \text {, hair, red blood } \\
\text { cells, bulk }\end{array}$ & $\begin{array}{l}\text { Strong correlation with the } \omega-3 \text { fatty acids, eicosapentaenoic acid (EPA) and } \\
\text { docosahexaenoic acid (DHA) content, in red blood cell membranes based on intake in } \\
144 \text { Yup'ik Eskimos; } \\
\text { Background: EPA and DHA have been suspected to protect against diabetes and other } \\
\text { metabolic syndrome components. }\end{array}$ & {$\left[9^{\bullet}, 56\right]$} \\
\hline${ }^{13} \mathrm{C}$, plasma glucose & $\begin{array}{l}\text { Randomized, single-blinded, cross-over study of five participants consuming diets with } \\
5,16 \text {, or } 32 \% \text { carbohydrate }(\mathrm{CHO}) \text { energy from } \mathrm{C}_{4} \text { sugars; } \\
\text { Reflection of changes in the fraction of dietary } \mathrm{CHO} \text { derived from cane sugar and high } \\
\text { fructose corn syrup (HFCS); } \\
\text { Directly proportional to the relative } \mathrm{C}_{4} \text { caloric sweetener content of a previous meal; } \\
\text { Background: high intake of high fructose corn syrup (HFCS) and refined sugars may } \\
\text { contribute to excessive energy intake and risk for obesity and metabolic syndrome } \\
\text { components. }\end{array}$ & [63] \\
\hline${ }^{13} \mathrm{C}$, in serum retinol & $\begin{array}{l}\text { Decreasing values in a group ( } n=20) \text { increasing vegetable consumption to promote } \\
\text { weight loss compared to a group }(n=17) \text { with caloric (fat) reduction. } \\
\delta^{13} \text { C-Retinol changes reflect the vitamin A source in the diet and can be used as a } \\
\text { biomarker for increased dietary provitamin A vegetable intake; } \\
\text { Background: test of guidelines for vegetable and fruit intake. }\end{array}$ & [64] \\
\hline${ }^{2} \mathrm{H},{ }^{18} \mathrm{O}$, hair, bulk & $\begin{array}{l}\text { Dominant control of environmental water } \delta \text {-values; } \\
\text { Secondary influences of a marine-based diet; } \\
\text { Reconstruction of geographic movements of individuals. }\end{array}$ & {$\left[6,7^{\bullet}\right]$} \\
\hline $\begin{array}{l}{ }^{15} \mathrm{~N} \text {, hair, } \\
\text { phenylalanine }\end{array}$ & $\begin{array}{l}\text { Negative correlation with consumption of low-energy drinks and food due to an } \\
\text { increased intake of aspartame, a significant source of phenylalanine; } \\
\text { Background: lower risk for metabolic syndrome components. }\end{array}$ & $\begin{array}{l}\text { Petzke KJ, } \\
\text { unpublished }\end{array}$ \\
\hline
\end{tabular}

CSIA, compound-specific isotope analysis.

physiological states. These important isotopic discoveries at the bulk protein level suggest that the individual amino acids in the bulk protein may also fractionate in unique patterns that can be used to better understand and diagnose perturbations in human nitrogen balance. Therefore, the measurement of stable isotope ratios may have the potential for not only objectively describing nutritional exposure but also diagnosing diet-related diseases.

\section{Equilibrium time of hair $\delta$-values after exposure}

A question that remains to be resolved is how fast can dietary or physiological exposures exhibit influences on human hair $\delta$-values? Previous studies have shown that hair $\delta^{15} \mathrm{~N}$ and $\delta^{13} \mathrm{C}$ values may change rapidly by $1-2 \%$ during 4-weeks starvation, the recovery phases from anorexia nervosa [12], and during nutritional stress as a 
Table 2 Human stable isotope ratio studies supporting the evidence of $\delta$-values as a tool in metabolic state and disease detection

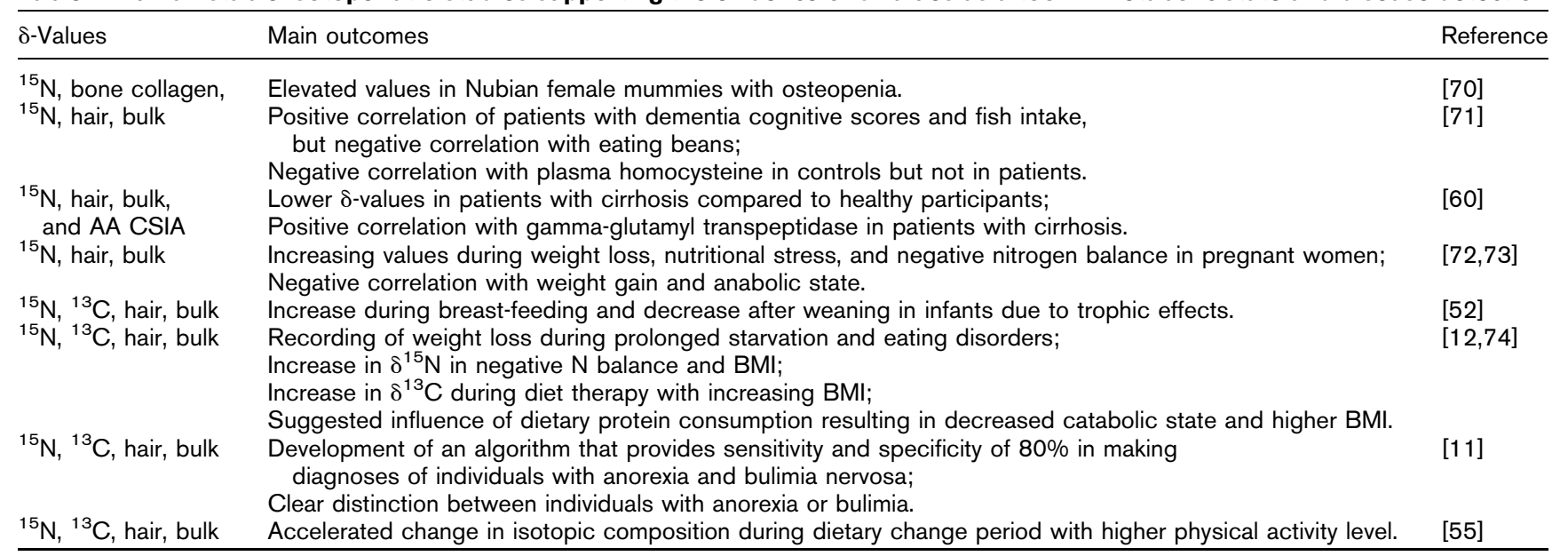

$\mathrm{AA}$, amino acid; CSIA, compound-specific isotope analysis.

result of nausea and vomiting from morning sickness in pregnant women [73]. An exponential approach of the $\delta^{2} \mathrm{H}$ and $\delta^{18} \mathrm{O}$ values to a new location suggested a $95 \%$ turnover after 3 months of arrival in a new city with dissimilar $\delta$-values of drinking water [27]. When $\delta^{13} \mathrm{C}$ values in hair were extrapolated after a change in dietary exposure as a result of moving between the UK and USA, a period of 2.3-4.0 months was calculated for the velocity of exchange of $\delta^{13} \mathrm{C}$ to a new steady state [46]. This period was found to be in accordance with those reported for complete exchange of the body carbon pool [55]. Furthermore, a faster exchange rate (1.3-3.2 times) was demonstrated for $\delta^{15} \mathrm{~N}$. Interestingly, a higher physical activity level significantly accelerated this isotopic exchange [55]. O'Connell and Hedges [2] detected equilibrium over the first 5 months of measuring $\delta^{15} \mathrm{~N}$ values in hair of an individual who changed from an omnivorous to a vegan diet, followed by a slower ongoing equilibration up to 1 year after the change. Consequently, the $\delta$-values of hair can only report in the long-term about nutritional exposures or pathophysiological histories. Various physiological factors are suspected to exert a significant influence on isotopic equilibration time in humans. For the interpretation of the results, it is important to consider the rate of protein turnover and the protein intake level with its

Figure 2 Plots of $\delta^{15} \mathrm{~N}$ against $\delta^{13} \mathrm{C}$ values of leucine, threonine, glutamic acid $(\alpha \mathrm{N})$, and glycine selected of wheat gluten ( $\mathrm{C}_{3}$ plant), pork fillet (Germany), and hair of young German women after consuming $200 \mathrm{~g}$ pork fillet per day in addition to their habitual diet for 4 weeks These results cover the spectrum of $\delta$-values to be expected in human nutrition studies

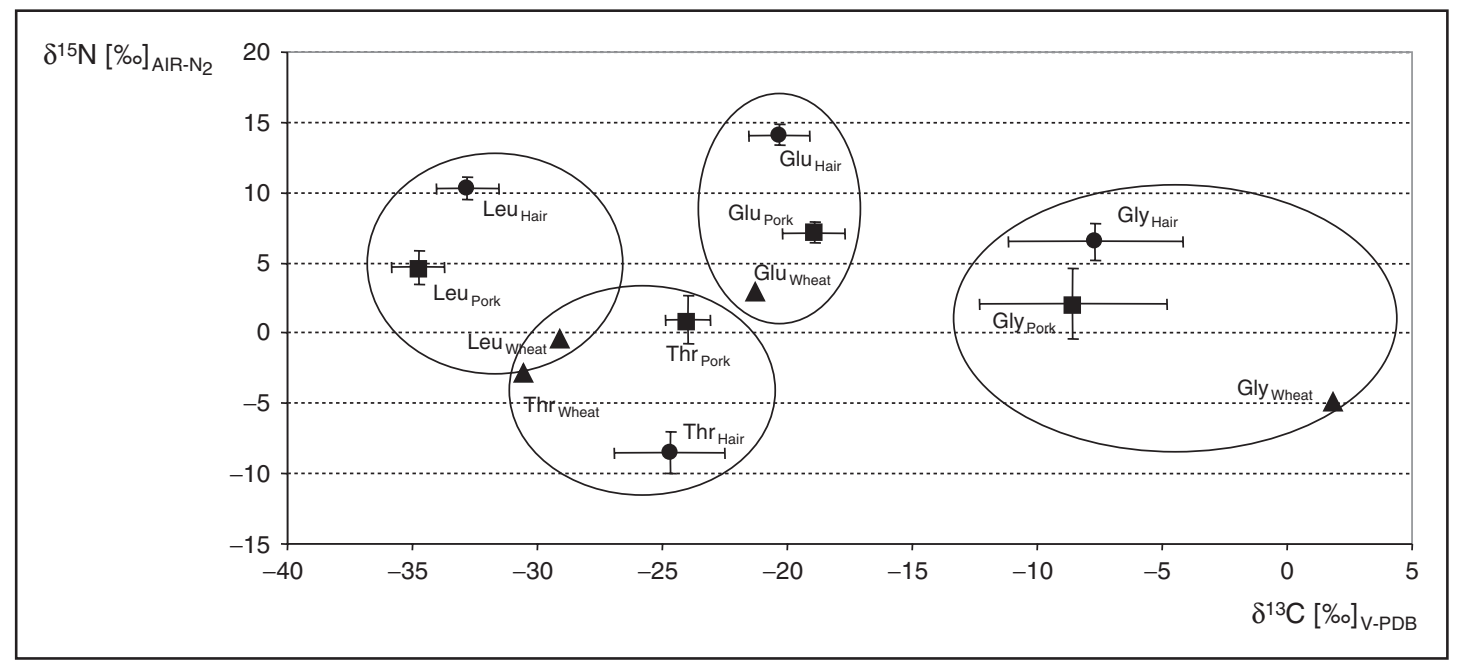

The standard deviations are presented for values of pork fillet and hair $(n=14)$. Note that each amino acid has its characteristic pool of $\delta$-values. Additionally, the $\delta$-values reveal source-specific differences suggested to be based on trophic and physiological effects. Reproduced with permission from [32]. 
consequences on modifications in splanchnic amino acid metabolism and partitioning. Unfortunately, this could have contributed to the fact that a suspected change in hair $\delta$-values was not observed after a 4-week exposure to drastically modified meat intakes in a nutritional intervention study [32]. Finally, mathematical models used in animal ecology [13] have not been adapted for human hair research to describe the dynamics of isotopic incorporation and of dietary and physiological factors known to influence these dynamics with one exception on hair $\delta^{2} \mathrm{H}$ and $\delta^{18} \mathrm{O}$ values $\left[7^{\circ}\right]$.

\section{First applications of compound-specific isotope analysis to human hair}

Unfortunately, published reports of hair amino acidspecific $\delta$-values are still uncommon in nutritional and medical studies, currently encompassing our own studies $[3,32,57,60]$ and those from modern and archaeological human hair samples $[43,44,46]$. However, investigations at the CSIA level are essential to understand the role of dietary exposure or physiological influences on hair stable isotope ratios, particularly when justifying their use as a diagnostic tool and in epidemiological research. Previous research could detect distinct differences and changes in amino acid-specific hair $\delta^{15} \mathrm{~N}$ and $\delta^{13} \mathrm{C}$ values $[3,32,43,60]$. These changes are suspected to depend on protein turnover rates, influences of pathophysiological metabolic changes, and metabolic adaptations related to differences in habitual protein consumption, in addition to effects due to various isotopic signatures of dietary macronutrients. As the amount of data in this area of research is still limited, satisfactory explanations of the effects of dietary exposures, for example, with meat or meat-free diets are difficult at the moment [32]. However, first results are consistent with the specificity of individual amino acids in metabolic characteristics, partitioning, and degrees of indispensability (Figs 1 and 2).

\section{Conclusion}

We conclude that based on current advances in IRMS methods, human hair protein stable isotope ratio analysis can contribute new and important information to epidemiological and clinical nutritional studies. Research in the area of human hair stable isotope ratios is currently limited in number and is predominantly based on bulk protein analysis. Early research in this field supports the usefulness of human hair $\delta$-values as biomarkers of nutritional exposure and as a diagnostic tool for metabolic states and diseases. However, there is a significant need for more research to better understand the relationships between nutritional exposure and physiological factors in modulating the $\delta$-values. Application of natural CSIA on amino acid will certainly reveal important and novel insights into these relationships and provide further improvement in precision, accuracy, and feasibility.

\section{Acknowledgements}

The present work was supported by funding to K.J.P. of the Deutsche Forschungsgemeinschaft, Bonn, Germany (grant numbers: Pe 643/6-1 and $P$ e 643/9-1), and by the core budget of the German Institute of Human Nutrition Potsdam-Rehbruecke, Nuthetal, Germany, Max Planck Institute for Evolutionary Anthropology, Leipzig, Germany, and Leibniz Institute for Farm Animal Biology, Dummerstorf, Germany.

\section{References and recommended reading}

Papers of particular interest, published within the annual period of review, have been highlighted as:

- of special interest

-• of outstanding interest

Additional references related to this topic can also be found in the Current World Literature section in this issue (p. 597).

1 Musshoff F, Madea B. Analytical pitfalls in hair testing. Anal Bioanal Chem 2007; 388:1475-1494.

2 O'Connell TC, Hedges REM. Investigations into the effect of diet on modern human hair isotopic values. Am J Phys Anthropol 1999; 108:409-425.

3 Petzke KJ, Boeing $\mathrm{H}$, Metges $\mathrm{CC}$. Choice of dietary protein of vegetarians and omnivores is reflected in their hair protein ${ }^{13} \mathrm{C}$ and ${ }^{15} \mathrm{~N}$ abundance. Rapid Commun Mass Spectrom 2005; 19:1392-1400.

4 Bol R, Marsh J, Heaton THE. Multiple stable isotope $\left({ }^{18} \mathrm{O},{ }^{13} \mathrm{C},{ }^{15} \mathrm{~N}\right.$ and $\left.{ }^{34} \mathrm{~S}\right)$ analysis of human hair to identify the recent migrants in a rural community in SW England. Rapid Commun Mass Spectrom 2007; 21:2951-2954.

5 Mützel E, Lehn $\mathrm{C}$, Peschel O, et al. Assignment of unknown persons to their geographical origin by determination of stable isotopes in hair samples. Int J Legal Med 2009; 123:35-40.

6 Thompson AH, Chesson LA, Podlesak DW, et al. Stable isotope analysis of modern human hair collected from Asia (China, India, Mongolia, and Pakistan). Am J Phys Anthropol 2010; 141:440-451.

7 Bowen GJ, Ehleringer JR, Chesson LA, et al. Dietary and physiological

- controls on the hydrogen and oxygen isotope ratios of hair from mid-20th century indigenous populations. Am J Phys Anthropol 2009; 139:494504.

This study supports the general applicability of a model for dietary and physiological controls on hair $\delta^{2} \mathrm{H}$ and $\delta^{18} \mathrm{O}$ values.

8 Hedges R, Rush E, Aalsbersberg W. Correspondence between human diet, body composition and stable isotopic composition of hair and breath in Fijian villagers. Isotopes Environ Health Stud 2009; 45:1-17.

9 Nash SH, Kristal AR, Boyer BB, et al. Relation between stable isotope ratios in

- human red blood cells and hair: implications for using the nitrogen isotope ratio of hair as a biomarker of eicosapentaenic acid and docosahexaenoic acid. Am J Clin Nutr 2009; 90:1642-1647.

Strong correlations were detected between hair $\delta^{15} \mathrm{~N}$ and red blood cell eicosapentaenic acid and docosahexaenoic acid supporting the use of hair stable isotope results as a biomarker of eicosapentaenic acid and docosahexaenoic acid intakes by marine foods in Yup'ik Eskimos. The validity of the method in populations with a more restricted intake of marine foods remains to be tested.

10 Sponheimer M, Codron A, Passey BH, et al. Using carbon isotopes to track dietary changes in modern, historical, and ancient primates. Am J Phys Anthropol 2009; 140:661-670.

11 Hatch KA, Crawford MA, Kunz AW, et al. An objective means of diagnosing anorexia nervosa and bulimia nervosa using ${ }^{15} \mathrm{~N} /{ }^{14} \mathrm{~N}$ and ${ }^{13} \mathrm{C} /{ }^{12} \mathrm{C}$ ratios in hair. Rapid Commun Mass Spectrom 2006; 20:3367-3373.

12 Mekota A-M, Grupe G, Ufer S, Cuntz U. Identifying starvation episodes using stable isotopes in hair. Rechtsmedizin 2009; 19:431-440.

13 Martinez del Rio C, Wolf N, Carleton SA, Gannes LZ. Isotopic ecology ten years after a call for more laboratory experiments. Biol Rev Camb Philos Soc 2009; 84:91-111.

14 Fraser I, Meier-Augenstein W, Kalin RM. The role of stable isotopes in human identification: a longitudinal study into the variability of isotopic signals in human hair and nails. Rapid Commun Mass Spectrom 2008; 20:11091116

15 Macko SA, Engel MH, Andrusevich V, et al. Documenting the diet in ancient human populations through stable isotope analysis of hair. Phil Trans R Soc Lond B 1999; 354:65-76. 
16 Schwertl M, Auerswald K, Schnyder H. Reconstruction of isotopic history of animal diets by hair segmental analysis. Rapid Commun Mass Spectrom 2007; 17:1312-1318.

17 Meier-Augenstein W. Applied gas chromatography coupled to isotope ratio mass spectrometry. J Chromatogr A 1999; 842:351-371.

18 Schmidt HL, Werner RA, Roßmann A, et al. Stable isotope ratio analysis in quality control of flavourings. Flavourings. In: Ziegler $\mathrm{H}$, editor. Weinheim, Germany: WILEY-VCH Verlag GmbH and Co. KGaA; 2007. pp. 602-663.

19 Lichtfouse E. Compound-specific isotope analysis. Applications to archaeology, biomedical sciences, biosynthesis, environment, extraterrestrial chemistry, food science, forensic science, humic substances, microbiology, organic geochemistry, soil science and sport. Rapid Commun Mass Spectrom 2000; 14:1337-1344.

20 Brand WA. Mass spectrometer hardware for analyzing stable isotope ratios. In: de Groot PA, editor. Handbook of stable isotope analytical techniques. Amsterdam: Elsevier; 2004. pp. 835-856.

21 Benson S, Lennard C, Maynard P, Roux C. Forensic applications of isotope ratio mass spectrometry: a review. Forensic Sci Int 2006; 10:1-22.

22 Sessions AL. Isotope-ratio detection for gas chromatography. J Sep Sci 2006; 29:1946-1961.

23 Godin JP, Fay LB, Hopfgartner G. Liquid chromatography combined with mass spectrometry for ${ }^{13} \mathrm{C}$ isotopic analysis in life science research. Mass Spectrom Rev 2007; 26:751-774.

24 Muccio Z, Jackson GP. Isotope ratio mass spectrometry. Analyst 2009; 134:213-222.

25 Werner RA, Brand WA. Referencing strategies and techniques in stable isotope ratio analysis. Rapid Commun Mass Spectrom 2001; 15:501-519.

26 Meier-Augenstein W, Fraser I. Forensic isotope analysis leads to identification of a mutilated murder victim. Sci Justice 2008; 48:153-159.

27 Eheleringer JR, Bowen GJ, Chesson LA, et al. Hydrogen and oxygen isotope ratios in human hair are related to geography. Proc Natl Acad Sci U S A 2008; 105:2788-2793.

28 O'Brien DM, Wooler MJ. Tracking human travel using stable oxygen and hydrogen isotope analysis of hair and urine. Rapid Commun Mass Spectrom 2007; 21:2422-2430.

29 Santamaria-Fernandez R, Martinez-Sierra JG, Marchante-Gayon JM, et al. Measurement of longitudinal sulphur isotopic variations by laser ablation MCICP-MS in single human hair strands. Anal Bioanal Chem 2009; 394:225233.

30 Santamaria-Fernandez R. Precise and traceable carbon isotope ratio measurements by multicollector ICP-MS: what next? Anal Bioanal Chem 2010; 397:973-978.

31 O'Connell TC, Hedges REM. Isolation and isotopic analysis of individual amino acids from archaeological bone collagen: a new method using RPHPLC. Archaeometry 2001; 43:421-438.

32 Petzke $\mathrm{KJ}$, Lemke S. Hair protein and amino acid ${ }^{13} \mathrm{C}$ and ${ }^{15} \mathrm{~N}$ abundances take more than 4 weeks to clearly prove influences of animal protein intake in young woman with a habitual daily protein consumption of more than $1 \mathrm{~g}$ per kg body weight. Rapid Commun Mass Spectrom 2009; 23:2411-2420.

33 Corr LT, Berstan R, Evershed RP. Development of N-acetyl methyl ester derivatives for the determination of $\delta^{13} \mathrm{C}$ values of amino acids using gas chromatography-combustion- isotope ratio mass spectrometry. Anal Chem 2007; 79:9082-9090.

34 Corr LT, Berstan R, Evershed RP. Optimisation of derivatisation procedures for the determination of $\delta^{13} \mathrm{C}$ values of amino acids by gas chromatography/ combustion/isotope ratio mass spectrometry. Rapid Commun Mass Spectrom 2007; 21:3759-3771.

35 Metges CC, Daenzer M. ${ }^{13} \mathrm{C}$ gas chromatography-combustion isotope ratio mass spectrometry analysis of $\mathrm{N}$-pivaloyl amino acid esters of tissue and plasma samples. Anal Biochem 2000; 278:156-164.

36 Docherty G, Jones V, Evershed RP. Practical and theoretical consideration in the gas chromatography/combustion/isotope ratio mass spectrometry $\delta^{13} \mathrm{C}$ analysis of small polyfunctional compounds. Rapid Commun Mass Spectrom $2001 ; 15: 730-738$

37 Hofmann D, Gehre M, Jung K. Sample preparation techniques for the determination of natural ${ }^{15} \mathrm{~N} /{ }^{14} \mathrm{~N}$ variations in amino acids by gas chromatography-combustion-isotope ratio mass spectrometry (GC-C-IRMS). Isotopes Environ Health Stud 2003; 39:233-244.

38 Petzke KJ, Daenzer M, Backes G, Metges CC. Analysis of stable nitrogen and carbon isotope enrichment in biological samples by GC-C-IRMS with special reference to amino acids. In: Pandalai SG, editor. Recent research developments in analytical biochemistry. Kerala, India: Transworld Research Network; 2002. pp. 45-63.
39 Sacks GL, Brenna JT. ${ }^{15} \mathrm{~N} /{ }^{14} \mathrm{~N}$ position-specific isotopic analyses of polynitrogenous amino acids. Anal Chem 2005; 77:1013-1019.

40 Zhang L, Altabet MA. Amino-group specific natural abundance nitrogen isotope ratio analysis in amino acids. Rapid Commun Mass Spectrom 2008; 22:559-566

41 Godin JP, Breuille D, Obled C, et al. Liquid and gas chromatography coupled to isotope ratio mass spectrometry for the determination of ${ }^{13} \mathrm{C}$-valine isotopic ratios in complex biological samples. J Mass Spectrom 2008; 43:13341343.

42 Krummen $M$, Hilkert AW, Juchelka $D$, et al. A new concept for isotope ratio monitoring liquid chromatography/mass spectrometry. Rapid Commun Mass Spectrom 2004; 18:2260-2266.

43 Smith Cl, Fuller BT, Choy K, Richards MP. A three-phase liquid chromatographic method for $\delta{ }^{13} \mathrm{C}$ analysis of amino acids from biological protein hydrolysates using liquid chromatography-isotope ratio mass spectrometry. Anal Biochem 2009; 390:165-172.

44 Raghavan M, McCullagh JS, Lynnerup N, Hedges RE. Amino acid $\delta^{13} \mathrm{C}$ analysis of hair proteins and bone collagen using liquid chromatography/ isotope ratio mass spectrometry: paleodietary implications from intraindividual comparisons. Rapid Commun Mass Spectrom 2010; 24:541548.

45 Bol R, Pflieger C. Stable isotope $\left({ }^{13} \mathrm{C},{ }^{15} \mathrm{~N}\right.$ and $\left.{ }^{34} \mathrm{~S}\right)$ analysis of the hair of modern humans and their domestic animals. Rapid Commun Mass Spectrom 2002; 16:2195-2200.

46 McCullagh JSO, Tripp JA, Hedges REM. Carbon isotope analysis of bulk keratin and single amino acids from British and North American hair. Rapid Commun Mass Spectrom 2005; 19:3227-3231.

47 Buchardt B, Bunch V, Helin P. Fingernails and diet: stable isotope signatures of a marine hunting community from modem Uummannaq, North Greenland. Chem Geol 2007; 244:316-329.

48 Richards MP, Trinkaus E. Isotopic evidence for the diets of European Neanderthals and early modern humans. Proc Natl Acad Sci U S A 2009; 106:16034-16039.

49 Cerling TE, Wittemyer G, Ehleringer JR, et al. History of animals using isotope records (HAIR): a 6-year dietary history of one family of African elephants. Proc Natl Acad Sci U S A 2009; 106:8093-8100.

50 Fraser I, Meier-Augenstein W, Kalin RM. The role of stable isotopes in human identification: a longitudinal study into the variability of isotopic signals in human hair and nails. Rapid Commun Mass Spectrom 2006; 20:11091116.

51 Hedges REM, Reynard LM. Nitrogen isotopes and the trophic level of humans in archaeology. J Archaeol Sci 2007; 34:1240-1251.

52 Fuller BT, Fuller JL, Harris DA, Hedges REM. Detection of breastfeeding and weaning in modern human infants with carbon and nitrogen stable isotope ratios. Am J Phys Anthropol 2006; 29:279-293.

53 Richards MP, Fuller BT, Sponheimer M, et al. Sulphur isotopes in palaeodietary studies: a review and results from a controlled feeding experiment. Int J Osteoarchaeol 2003; 13:37-45.

54 Caut S, Angulo E, Courchamp F. Discrimination factors $\left(\Delta^{15} \mathrm{~N}\right.$ and $\left.\Delta^{13} \mathrm{C}\right)$ in an omnivorous consumer: effect of diet isotopic ratio. Funct Ecol 2008; 22:255263.

55 Huelsemann F, Flenker U, Koehler K, Schaenzer W. Effect of a controlled dietary change on carbon and nitrogen stable isotope ratios of human hair. Rapid Commun Mass Spectrom 2009; 23:2448-2454.

56 O'Brien DMO, Kristal AR, Jeannet MA, et al. Red blood cell $\delta^{15} \mathrm{~N}$ : a novel biomarker of dietary eicosapentaenoic acid and docosahexaenoic acid intake. Am J Clin Nutr 2009; 89:913-919.

57 Petzke KJ, Boeing $\mathrm{H}$, Klaus S, Metges CC. Carbon and nitrogen stable isotopic composition of hair protein and amino acids can be used as biomarkers for animal-derived dietary protein intake in humans. J Nutr 2005; 135:1515-1520.

58 Jahren $\mathrm{AH}$, Saudek $\mathrm{C}$, Yeung $\mathrm{EH}$, et al. An isotopic method for quantifying sweeteners derived from corn and sugar cane. Am J Clin Nutr 2006; 84: $1380-1384$.

59 Werner RA, Schmidt HL. The in vivo nitrogen isotope discrimination among organic plant compounds. Phytochem 2002; 61:465-484.

60 Petzke KJ, Feist T, Fleig WE, Metges CC. Nitrogen isotopic composition in hair protein is different in liver cirrhotic patients. Rapid Commun Mass Spectrom 2006; 20:2973-2978.

61 Kraft RA, Jahren $A H$, Saudek $C D$. Clinical-scale investigation of stable isotopes in human blood: $\delta^{13} \mathrm{C}$ and $\delta^{15} \mathrm{~N}$ from 406 patients at the Johns Hopkins Medical Institutions. Rapid Commun Mass Spectrom 2008; 22: 3683-3692. 
62 Wilkinson MJ, Yai Y, O'Brien DM. Age-related variation in red blood cell stable isotope ratios $\left(\delta^{13} \mathrm{C}\right.$ and $\left.\delta^{15} \mathrm{~N}\right)$ from two Yupik villages in Southwest Alaska: a pilot study. Int J Circumpolar Health 2007; 66:31-41.

63 Cook CM, Alvig AL, Liu YQ, Schoeller DA. The natural ${ }^{13} \mathrm{C}$ abundance of plasma glucose is a useful biomarker of recent dietary caloric sweetener intake. J Nutr 2010; 140:333-337.

64 Howe JA, Valentine AR, Hull AK, Tanumihardjo SA. ${ }^{13} \mathrm{C}$ natural abundance in serum retinol acts as a biomarker for increases in dietary provitamin A. Exp Biol Med 2009; 234:140-147.

65 Potischman N. Biologic and methodologic issues for nutritional biomarkers. J Nutr 2003; 133:875S-880S.

66 Maruvada P, Srivastava S. Biomarkers for cancer diagnostics: implications for nutritional research. J Nutr 2004; 134:1640S-1645S.

67 Jim S, Jones V, Ambrose SH, Evershed RP. Quantifying dietary macronutrient sources of carbon for bone collagen biosynthesis using natural abundance stable carbon isotope analysis. Br J Nutr 2006; 95:1055-1062.

68 Guggenheim KY. Rudolf Schoenheimer and the concept of the dynamic state of body constituents. J Nutr 1991; 121:1701-1704.
69 Wolfe RR, Chinkes DL. Isotope tracers in metabolic research: principles and practice of kinetic analysis. Hoboken, NJ, USA: John Wiley \& Sons Inc.; 2005.

70 White CD, Armelagos GJ. Osteopenia and stable isotope ratios in bone collagen of Nubian female mummies. Am J Phys Anthropol 1997; 103:185199.

71 Williams JH, O'Connell TC. Differential relations between cognition and ${ }^{15} \mathrm{~N}$ isotopic content in hair in elderly people with dementia and controls. J Gerontol A Biol Sci Med Sci 2002; 57A:M797-M802.

72 Fuller BT, Fuller JL, Sage NE, et al. Nitrogen balance and $\delta^{15} \mathrm{~N}$ : why you're not what you eat during pregnancy. Rapid Commun Mass Spectrom 2004; 18:2889-2896.

73 Fuller BT, Fuller JL, Sage NE, et al. Nitrogen balance and $\delta^{15} \mathrm{~N}$ : why yoúre not what you eat during nutritional stress. Rapid Commun Mass Spectrom 2005; 19:2497-2506.

74 Mekota AM, Grupe G, Ufer S, Cuntz U. Serial analysis of stable nitrogen and carbon isotopes in hair: monitoring starvation and recovery phases of patients suffering from anorexia nervosa. Rapid Commun Mass Spectrom 2006; 20:1604-1610. 